\title{
Experimental and theoretical investigation of mass transfer in a cooling tower
}

\section{Igor Kuzmenko,}

\section{Roman Prokopets}

NTUU "Kyiv Polytechnical Institute",

Peremogy St. 37,

03056 Kiev, Ukraine

E-mail:ozirno@ukr.net
The mass transfer coefficient for a cooling tower is determined experimentally and theoretically. Contribution of a diffusion and convection component into mass transfer is estimated. The assessment showed that the contribution of the convection component into mass transfer can be neglected.

Thickness of the diffusion layer was experimentally measured and compared with the theoretically obtained hydrodynamic displacement layer. The calculation of the mass transfer coefficient uses the displacement layer. It is demonstrated that the difference between experimental data and simulation results does not exceed $33 \%$ in the range of air velocity of $(1.3-3.0) \mathrm{m} / \mathrm{s}$.

Key words: cooling tower, mass transfer, hydraulic displacement layer, Merkel equation

\section{INTRODUCTION AND PROBLEM FORMULATION}

Simulation of cooling towers requires the calculation of the volume of the heat and the evaporated water. These parameters depend on the consumption of water and air, their relative velocities, contact surface, input water and air temperatures.

Studies of the heat and mass transfer during the evaporative cooling of the liquid film in the gas flow should be divided into two groups.

The first group is based on the liquid heat balance equation (Merkel's Equation) and suggests that the Lewis analogy [1-4] exists:

$$
G_{3} c_{3} d t=G_{2} d h=\beta\left(h_{s}-h_{w}\right) d f .
$$

Equation (1) shows that the changes of heat in the film rely on the evaporating water film. This equation gives good results if temperature of the water film equals wet-bulb temperature [5].

The second group of studies on the heat and mass transfer during the evaporative cooling of the liquid film is based on the heat transfer equations for the liquid film and air. Next equations describe cooling and humidification of air at concurrent coolant flow $[6,7]$.

Energy equations for the water film:

$$
\rho_{3} c_{3} U \frac{\partial T_{3}}{\partial x}=\frac{\partial}{\partial y}\left[\lambda_{3} \frac{\partial T_{3}}{\partial y}\right]
$$


Energy equation for air:

$\rho_{2} c_{2} W \frac{\partial T_{2}}{\partial x}=\frac{\partial}{\partial y}\left[\lambda_{2} \frac{\partial T_{2}}{\partial y}\right]$

Concentration:

$W \frac{\partial \rho_{1}}{\partial x}=\frac{\partial}{\partial y}\left[D \frac{\partial \rho_{1}}{\partial y}\right] ;$

The heat balance:

$Q_{3}+Q_{1}=Q_{2}$

After specifying the thermal and concentration boundary conditions, the system (2-5) is solved numerically.

In the studies $[11,12]$ the system $(2-5)$ is supplemented by the equations, which take into account the reduction of the film thickness during the evaporation in the cooling tower. However, it complicates the model and increases the deviation from the experimental results.

Another system of ordinary differential equations with known values of the heat and mass transfer coefficients has the analytical solution [8-10], which provides the final temperatures of water and air as well as partial pressure of vapour in the air.

A generalized model of hydrodynamics, heat and mass transfer in the concurrent flow is specified in [13-16]. For this model the deviation is up to $33 \%$ of the output temperatures values, however, the model enables the analytical description of mass transfer in the cooling tower.

There are some disadvantages of the methods described above. The experimental value of the heat and mass transfer coefficients gives a variety of output temperatures and a partial pressure of vapour in the air. The Lewis analogy for determining the mass transfer coefficient can be fulfilled or not. So, the objective of the paper is investigation of principles of calculation of the mass transfer coefficient in a cooling tower. The following tasks are performed:

- Values of the diffusion and convection mass transfer are found experimentally and checked by theory. The comparison of the value of diffusion and convection mass transfer is performed;

- Coefficient of diffusion mass transfer is calculated according to the boundary layer theory. The experimental results were compared with simulation results.

\section{THEORY OF MASS EXCHANGE BETWEEN WATER AND AIR}

Let us assume that the mass transfer is carried out by the diffusion as the analogy of thermal conductivity and convection. Let us consider theoretically the combination of diffusion and convection mass transfers. There is water on the bottom of the glass tube (Fig. 1) and above the

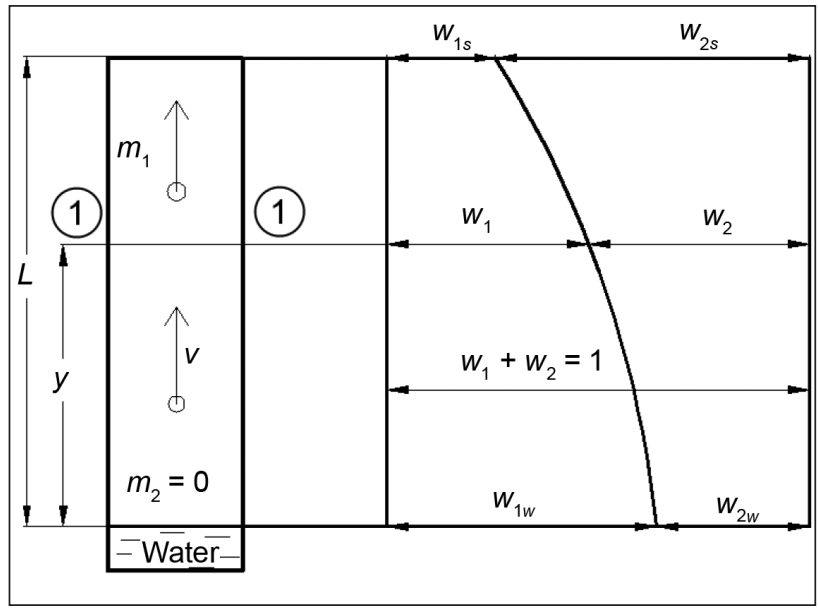

Fig. 1. Mass exchange by diffusion and convection

open end of the tube the air with the certain share of mass fraction of vapour $\omega_{1 s}[17]$ is moving.

The process in the tube takes place at the atmospheric pressure. Let us assume that the temperature in the tube is stable, the mass fraction of vapour $\omega_{1 s}$ outside the tube and above the surface is different. It is because the partial pressure of the vapour outside the tube and above the surface of water is different. Partial pressure of vapour above the water surface is equal to the saturation pressure according to the water temperature and the mass fraction of vapour $\omega_{1 w}=\frac{m_{1}}{m_{w}}$ corresponds to the saturated vapour with the temperature of water.

In the tube according to the Fick's first law there is a difference in the mass shares nearby the film and in the air and diffusion flow of the vapour.

Because the sum of mass shares is $\omega_{1}+\omega_{2}=\frac{m_{1}+m_{2}}{m}=$ $=1$, the gradient of the vapour mass share along the tube complies with the gradient of the air mass share. Thus, simultaneously with the vapour flow upwards the flow of air in the reverse direction, i. e. downwards, exists. Air diffusion also complies with the Fick's first law. That is why in order to compensate the diffusion movement of air downwards in the tube, the convection movement of air upwards appears.

Let us assume that the velocity of such convection vapour movement is $v$. The amount of vapour removed by the flow from the tube's area during the time span will be $\rho_{1} v_{1}$, where $v_{1}$ equals the air velocity $v$ calculated below. Thus, the total amount of vapour through the section 1-1 will be determined by the following expression:

$$
\dot{m}_{1}=-\rho D \frac{d \omega_{1}}{d y}+\rho_{1} v_{1} .
$$

Let us derive an expression for air flow. As this flow is equal to zero, the expression for the air flow will be

$$
\dot{m}_{2}=-\rho D \frac{d \omega_{2}}{d y}+\rho_{2} v_{2}=0
$$


From the equation above the velocity value is

$v_{2}=\frac{D}{\omega_{2}} \cdot \frac{d \omega_{2}}{d y}$.

The mass fraction of vapour in air will be expressed as $\omega_{2}=1-\omega_{1} ; \frac{d \omega_{2}}{d y}=-\frac{d \omega_{1}}{d y}$. As a result, we have $v_{1}=v_{2}=v$ because the vapour is created by the same air flow:

$$
v=-\frac{D}{1-\omega_{1}} \frac{d \omega_{1}}{d y}
$$

Taking into account $\rho+\frac{\rho_{1}}{1-\omega_{1}}=\frac{\rho^{2}}{\rho_{2}}$ vapour mass flow through the tube, according to Eq. (6), is the following:

$$
\dot{m}_{1}=-\rho D \frac{d \omega_{1}}{d y}-\frac{\rho_{1}}{1-\omega_{1}} D \frac{d \omega_{1}}{d y}=-\frac{\rho^{2}}{\rho_{2}} D \frac{d \omega_{1}}{d y}
$$

If the equation $v\left(1-\omega_{1}\right)=-\frac{D d \omega_{1}}{d y}$ from (7) is put into Eq. (6), the following expression is obtained:

$$
\begin{aligned}
& \dot{m}_{1}=-\rho D \frac{d \omega_{1}}{d y}+\rho_{1} v=\rho\left(1-\omega_{1}\right) v+\rho_{1} v=\rho v, \\
& \text { as } \rho v \omega_{1}=\frac{m}{V} \frac{m_{1}}{m} v=\rho_{1} v .
\end{aligned}
$$

In order to verify the dependencies (6-9) for mass transfer in the cooling tower, the experimental investigation was conducted.

\section{EXPERIMENTAL FACILITY AND METHODS OF ANALYSIS}

The processes of air humidification in the mode of hot water-cold air [18] in the cooling tower are conducted in the facility as shown in Fig. 2.

Water and air of constant humidity (see Table 1) and temperatures are fed to the scaled model of the cooling tower with corrugated netting packing (see Fig. 3) and countercurrent flow. The mass fraction of vapour is calculated from the heat balance.

The ranges of variation of the coolant flow and heat loss are defined during testing of the experimental facility. The heat loss was determined at a given volume of water and air.

The experiment was conducted varying air flow at a constant input temperature of water and air.

The main operating and geometrical parameters are specified in Table 1 . The input temperature of the water film and the velocity of air changes in the range $(63-85){ }^{\circ} \mathrm{C}$ and $(1.3-3) \mathrm{m} / \mathrm{s}$ at the experiments. The maximum dispersion

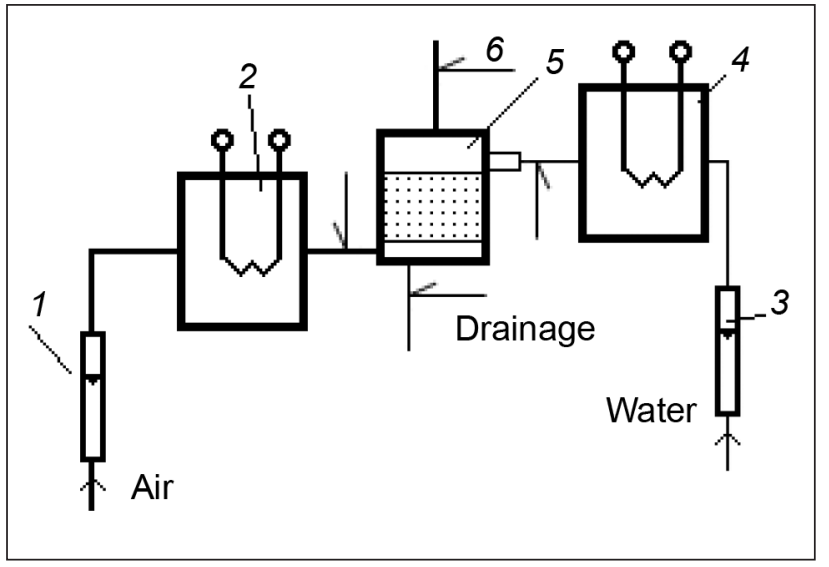

Fig. 2. The structure of experimental facility: 1,3-rotameters, 2, 4- electrical heaters, 5 - a scaled model of the cooling tower, 6 - thermocouples

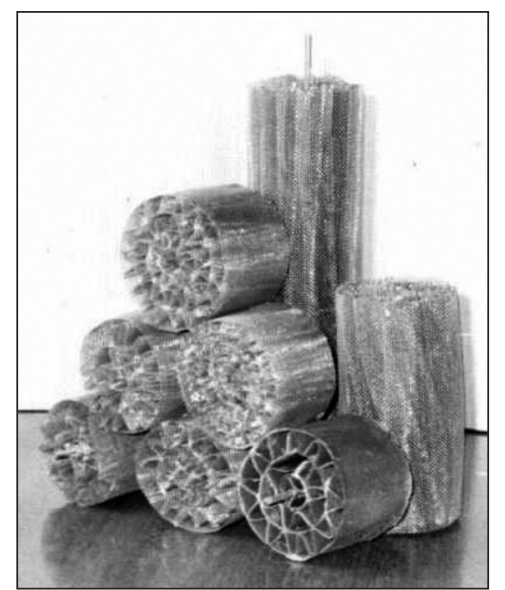

Fig. 3. Corrugated netting packing for a scaled model of the cooling tower

of the mass transfer coefficient does not exceed 5.7\% at repeating experiments [18].

The mass transfer coefficient in the scaled model of the cooling tower can be determined, knowing the input and output parameters of water and air, wetted area of the corrugated netting packing.

As the water film temperature is higher than the air (see Table 1), the air is heated and moisturized because of the difference of partial pressures.

During the experiment the volume of water and air at the output (measured by rotameters), temperatures of water and air at the input and output (measured by dry thermocouples) are obtained. The thermocouple of output

\begin{tabular}{|c|c|c|c|c|c|c|c|c|}
\hline \multicolumn{2}{|c|}{ Input temperature } & \multirow{2}{*}{$\begin{array}{l}\text { Input humidity } \\
\text { air, g/kg }\end{array}$} & \multirow{2}{*}{$\begin{array}{l}\text { Air velocity, } \\
\mathrm{m} / \mathrm{s}\end{array}$} & \multirow{2}{*}{$\begin{array}{l}\text { Water con- } \\
\text { centration, } \\
\mathrm{g} / \mathrm{m} / \mathrm{s}\end{array}$} & \multicolumn{4}{|c|}{ Corrugated netting packing } \\
\hline Water film, ${ }^{\circ} \mathrm{C}$ & Air, ${ }^{\circ} \mathrm{C}$ & & & & $\begin{array}{c}\text { Wetted } \\
\text { perimeter, } \mathrm{m}\end{array}$ & $\begin{array}{c}\text { Equivalent } \\
\text { diameter, } m\end{array}$ & $\begin{array}{l}\text { Height, } \\
\text { m }\end{array}$ & $\begin{array}{l}\text { Wetted } \\
\text { area, } m^{2}\end{array}$ \\
\hline $85(63)$ & 20 & 10 & $1.3 \div 3$ & 4 & 1.44 & $6.7 \cdot 10^{-3}$ & 0.1 & 0.144 \\
\hline
\end{tabular}
air can moisturize, thus it was protected by a screen. The results of the experiment are presented in Table 2.

Table 1. Main initial parameters 
Table 2. The results of the experiment

\begin{tabular}{|c|c|c|c|c|c|c|}
\hline No. & Water flow rate $G_{3}, \mathrm{~kg} / \mathrm{h}$ & Air flow rate $G_{2}, \mathrm{~m}^{3} / \mathrm{h}$ & $t_{\text {in } 2^{\prime}} \mathrm{C}$ & $t_{\text {out } 2^{\prime}}{ }^{\circ} \mathrm{C}$ & $t_{i n 3^{\prime}}{ }^{\circ} \mathrm{C}$ & $t_{\text {out } 3^{\prime}}{ }^{\circ} \mathrm{C}$ \\
\hline 1 & 28 & 26.6 & 20.4 & 42.4 & 63.2 & 38.6 \\
\hline 2 & 28 & 22.9 & 22.2 & 43.2 & 63.4 & 40.2 \\
\hline 3 & 28 & 19.19 & 22.8 & 44 & 62.2 & 41.2 \\
\hline 4 & 28.5 & 15.49 & 23.4 & 45.4 & 62 & 42.22 \\
\hline 5 & 27.5 & 12.43 & 23.6 & 47 & 64 & 45.4 \\
\hline 6 & 27.5 & 28.2 & 21 & 45.4 & 83.8 & 37 \\
\hline 7 & 27.5 & 28.1 & 21.2 & 48.4 & 83.8 & 37 \\
\hline 8 & 27.5 & 28.2 & 21.2 & 46.8 & 83.8 & 36.6 \\
\hline 9 & 27.5 & 28.2 & 21.2 & 47.6 & 84.2 & 36.6 \\
\hline 10 & 27.5 & 28.1 & 21.4 & 47 & 84.4 & 36.4 \\
\hline 11 & 27.5 & 18.5 & 21.8 & 50.2 & 85.6 & 41.4 \\
\hline 12 & 27.5 & 18.3 & 22 & 50.6 & 86.6 & 41 \\
\hline 13 & 27.5 & 18.6 & 22 & 49.2 & 85.6 & 40.8 \\
\hline 14 & 27.5 & 18.1 & 22 & 50.2 & 85.4 & 41 \\
\hline 15 & 27.1 & 18.6 & 22 & 49.8 & 87 & 41 \\
\hline 16 & 27.5 & 13.8 & 22.2 & 53.4 & 85.4 & 43.2 \\
\hline 17 & 27.3 & 13.7 & 21.8 & 52.8 & 85 & 43.6 \\
\hline 18 & 27.5 & 13.7 & 22 & 53.2 & 85.4 & 43.6 \\
\hline 19 & 27.5 & 13.7 & 21.4 & 53.2 & 85.2 & 43.8 \\
\hline 20 & 27.4 & 13.7 & 22 & 53 & 85.4 & 43 \\
\hline
\end{tabular}

The mass transfer coefficient that depends on the air velocity $W$ is calculated. The flow rate of the vapour is determined from the heat balance:

$$
G_{1}=\frac{G_{3} \cdot \rho_{3} \cdot c_{3}\left(t_{i n, 3}-t_{o u t, 3}\right)-G_{2} \rho_{2} \cdot c_{2}\left(t_{o u t, 2}-t_{i n, 2}\right)-Q_{l s}}{r_{1}} .
$$

The output absolute and relative humidity is calculated as follows:

$$
d_{\text {out }}=d_{\text {in }}+\frac{G_{1}}{G_{2}}, \varphi=p_{\text {out }} / p_{\max }
$$

where $d_{\text {in }}=0.01$.

The output vapour pressure and maximum vapour pressure in the air at the output air temperature were calculated:

$$
p_{\text {out }}=B \cdot \frac{d_{\text {out }}}{0.622+d_{\text {out }}}, p_{\max }=f\left(t_{\text {out }, 2}, \varphi=1\right)[8] .
$$

Whereas the heat balance cannot be verified (see Eq. 10) we check the existing correlation between $\varphi$ (from Eq. 11) and $W$. The data that reduce the Pearson correlation coefficient $R$ were excluded.

In Fig. 4 the dependence between the air humidity at the experimental facility, the air velocity and input water temperature is illustrated. The results at the input water temperature of $t_{i n, 3}=85^{\circ} \mathrm{C}$ have heat non-balance, which explains why the relative humidity $\varphi>1$. The experimental data at the air velocity $W<1.3 \mathrm{~m} / \mathrm{s}$ are excluded as they reduce the Pearson correlation coefficient $R$. Also, according to Fig. 4, the increase of velocity reduces the relative humidity of air, which does not become saturated.
Fig. 4. Dependence of the output relative humidity on the air velocity and input water temperature

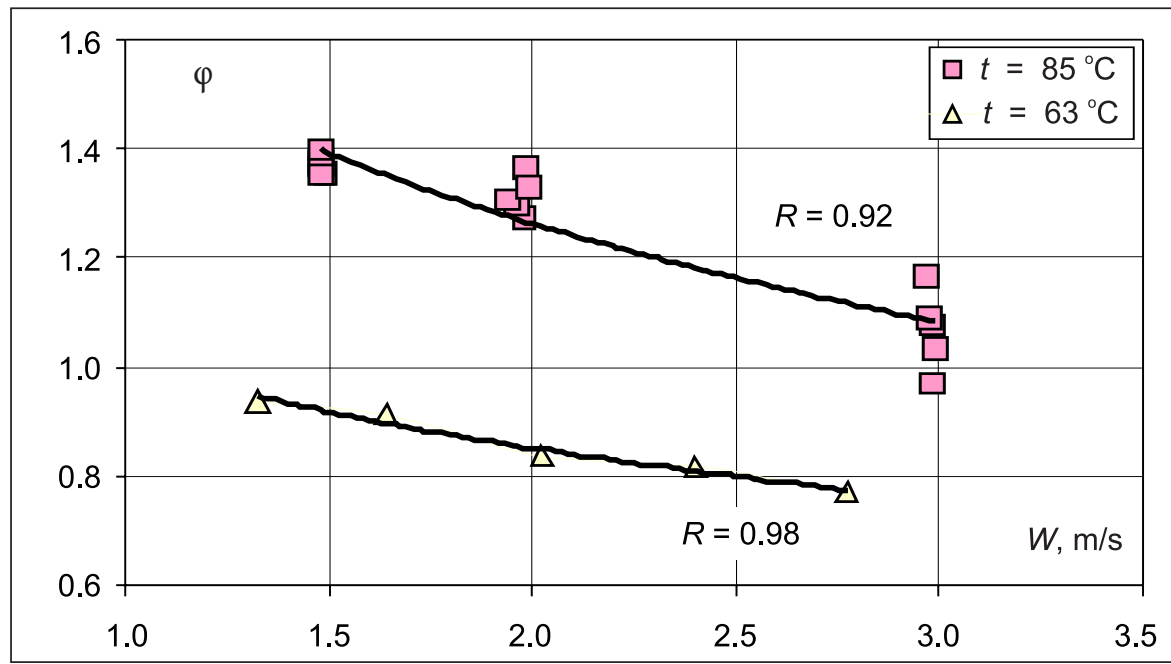




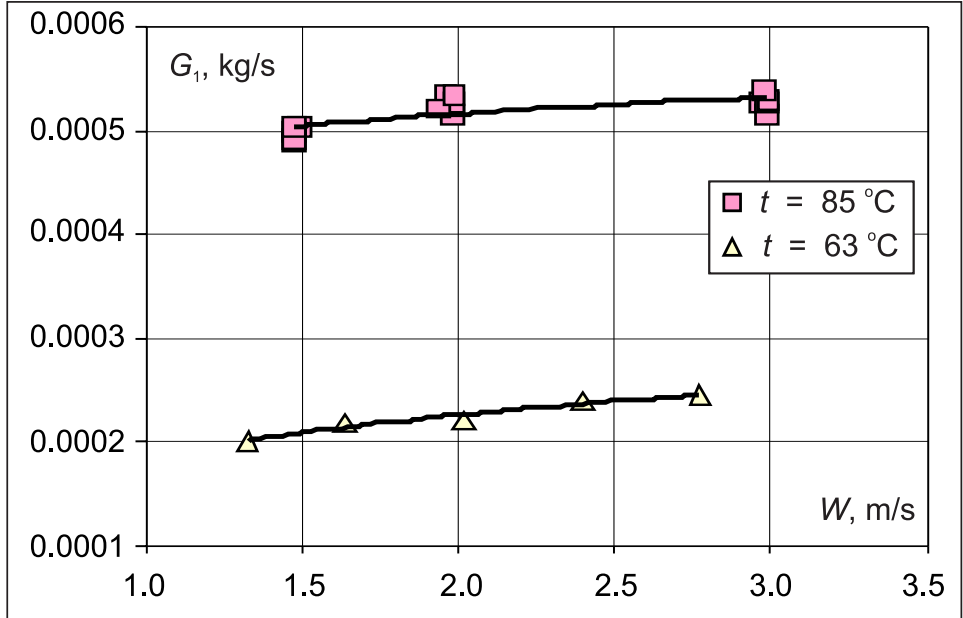

Fig. 5. Dependence of the flow rate of the vapour $G_{1}, \mathrm{~kg} / \mathrm{s}$ on the air velocity and input air temperature

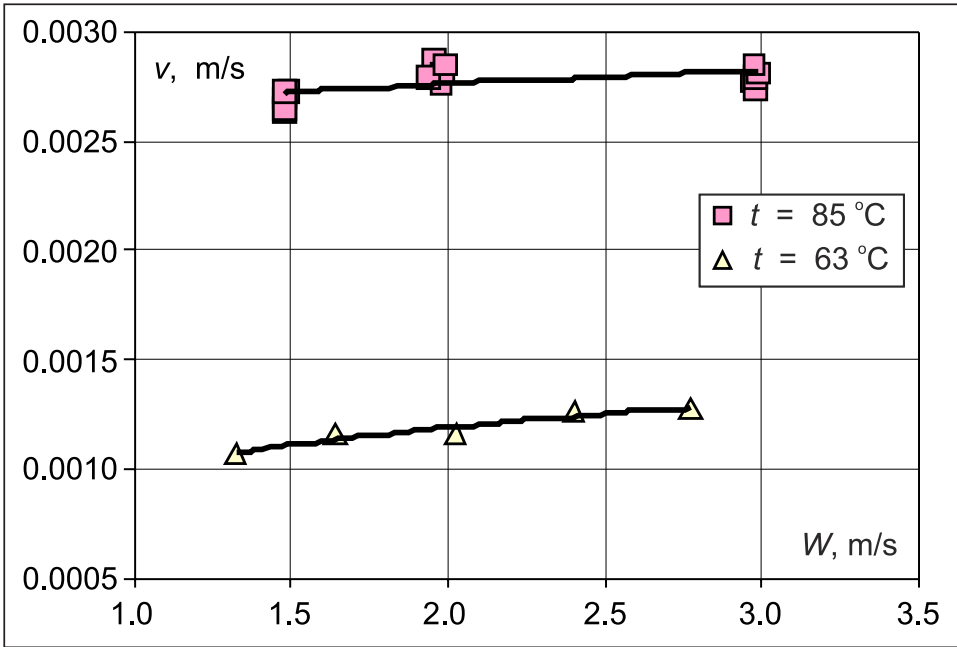

Fig. 6. Dependence of the velocity of the convection vapour flow from the water film surface on the air velocity and input air temperature

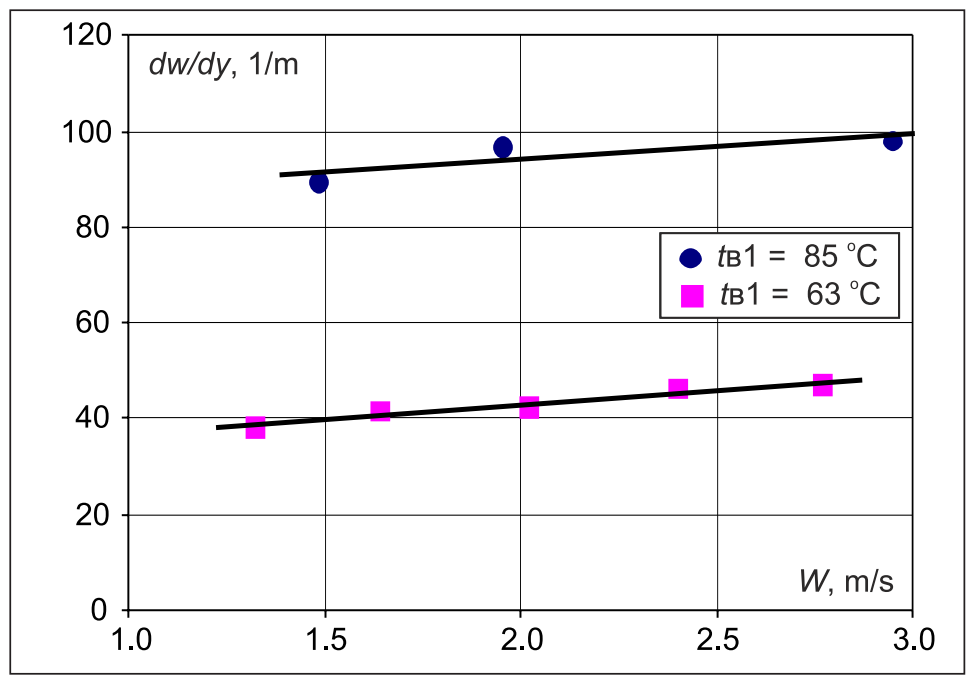

Fig. 7. Dependence of the mass content gradient on the air velocity and input water temperature
The increase of input water temperature increases the evaporation and saturation efficiency.

\section{THE RESULTS OF RESEARCH OF MASS TRANSFER IN THE COOLING TOWER}

Figure 5 shows the dependence of the flow rate of the vapour $G_{1}, \mathrm{~kg} / \mathrm{s}$ on the air velocity and input water temperature. In Fig. 5 it is shown that the input water temperature growth from 63 to $85{ }^{\circ} \mathrm{C}$ gives the increase $G_{1}$ by 2.5 times. However, the influence of the air velocity is negligible $( \pm 5 \%)$ because the evaporation in the cooling tower depends on the water film temperature that increases the gradient of temperature and pressure.

Let us consider the theoretical description of the mass transfer between the water and air. The obtained analytical dependences (67) will be compared with the experimental data.

From Eq. (9) and considering the wet air density is almost equal to the air density $\rho \sim \rho_{2}$, we have

$$
\mathrm{v}=\frac{\dot{m}_{1}}{\rho_{2}} .
$$

Knowing the velocity let us calculate the flow rate of the vapour at the expense of the convection and diffusion transfer. The results are shown in Fig. 5.

Velocity of the convective flow of vapour from the water film is specified in Fig. 6 and calculated by the formula:

$$
\mathrm{v}=\frac{1}{\rho_{2}}\left(\frac{G}{f}\right), \frac{m}{s} .
$$

According to Fig. 6, at high velocities and temperatures $v$ makes up to $3 \mathrm{~mm} / \mathrm{s}$ and is directly proportional to the water film temperature as well as the flow rate of vapour $G_{1}$.

From Eq. (7) we will determine the mass content gradient in the scalar form $\frac{d \omega_{1}}{d y}=\frac{v\left(1-\omega_{1}\right)}{D}$ as the mass transfer driving force.

Dependence on the air velocity and input water temperature is shown in Fig. 7. According to Fig. 7, the mass content gradient directly depends on the water temperature as well as the flow rate of vapour $G_{1}$. 
Hereby, the mass content calculation is performed as follows: $\omega_{1}=\frac{\rho_{1}}{\rho} \sim \rho_{1}$, where $\rho_{1}$ is the vapour density at the water film temperature.

The first additive component can be calculated in Eq. (6) by using $\frac{d \omega_{1}}{d y}$ (from Fig. 7) and the diffusion coefficient [8]:

$$
D=0.246 \cdot 10^{-4}\left(\frac{273+t}{273}\right)^{1.8}, \mathrm{~m}^{2} / \mathrm{s}
$$

Taking into account Eq. (8) in consideration of $\rho \sim \rho_{2}$, we have

$$
\dot{m}_{1}=-\frac{\rho^{2}}{\rho_{2}} D \frac{d \omega_{1}}{d y} \cong-\rho D \frac{d \omega_{1}}{d y} .
$$

This theoretical Eq. (14) shows that we can ignore the convection mass transfer component in general mass flow. The experimental data in Figs. 8 and 9 demonstrate it - the diffusion mass transfer component much more than convection mass transfer.

Figure 8 shows $D m$ - the diffusion component of mass transfer depending on some parameters. According to Fig. 8, change of the diffusion mass transfer component was conditioned by the mass content gradient depending on the water temperature as well as the velocity of convection vapour flow.

The second additive component in Eq. (6) characterizes the convection mass transfer. The divergence of calculation of the right and left part of the equation $\rho_{1} v=\dot{m}_{1}-\rho D \frac{d \omega_{1}}{d v}$ does not exceed $2.4 \%$. That is a good characteristic for this method of calculation.

Figure 9 shows the dependence of the convection mass transfer component on the air velocity and water temperature. The comparison of Figs. 8 and 9 reveals that the diffusion mass transfer component is in one order higher than the convection mass transfer component and proves the theoretical equation (14) experimentally.

Figure 9 presents convective mass transfer reducing at the increasing air velocity in the water temperature of $85^{\circ} \mathrm{C}$. The growth of air velocity increases the heat transfer from water to air (see Fig. 9). This reduces the water temperature and the flow of vapour. Thus, the growth of air velocity increases heat transfer and subsequently reduces the latent heat vaporization and convective mass transfer.

Let us derive the dependence (14) in the scalar form:
Fig. 8. Dependence of the diffusion mass transfer component on the air velocity and input water temperature

Fig. 9. Dependence of the convection mass transfer component on the air velocity and input water temperature
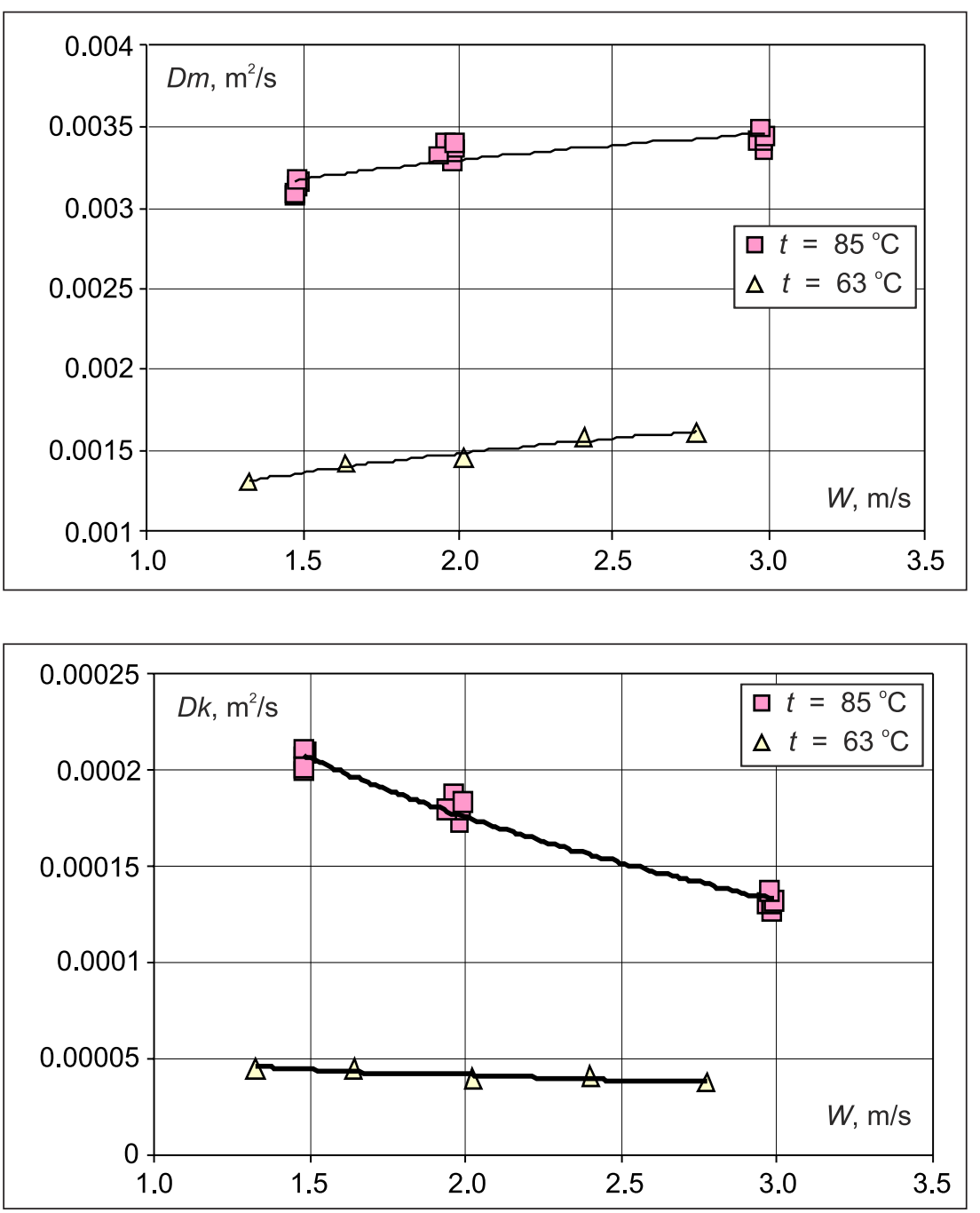


$$
\frac{\dot{m}_{1}}{\Delta \omega_{1}} \frac{1}{\rho D}=\frac{1}{\Delta y}
$$

where $\Delta \omega_{1}=\omega_{1 w}-\omega_{1 s}=\rho_{w}-\rho_{s} ; \Delta y$ is the thickness of the diffusion layer, where the mass content gradient levelling is performed.

On the other hand, it is known that the mass transfer coefficient is

$$
\beta c=\frac{\dot{m}_{1}}{\Delta \omega_{1}}
$$

or $\beta c \frac{1}{\rho D}=\frac{1}{\Delta y}$, where $\frac{1}{\rho D}=$ const. That is, the coefficient $\beta c$ is inversely proportional to the thickness of the diffusion layer.

The theoretical thickness of the diffusion layer is calculated according to the boundary layer theory [19] since the hydraulic displacement layer thickness does not depend on the water temperature:

$$
\delta=1.75 \cdot \sqrt{\frac{v_{2} x}{v}},
$$

where $x=0.05 \mathrm{~m}$ is the average value of the corrugated netting packing scaled model of the cooling tower.
On the other hand, the thickness of the diffusion layer is calculated by processing experimental results from Eq. (15). The theoretical and experimental thicknesses are presented in Fig. 10 and decrease with the growth of the input water temperature and air velocity. The thickness of the hydraulic displacement layer differs from the experimental thickness of the diffusion layer by up to $38 \%$. However, the decrease of the thickness of the hydraulic displacement layer or the diffusion layer at the input water temperature $63{ }^{\circ} \mathrm{C}$ intensifies the mass transfer process as it is shown in Fig. 11.

According to Fig. 11, the main factor of influence is the temperature of input water. That is, the growth of the input water temperature from $63{ }^{\circ} \mathrm{C}$ to $85{ }^{\circ} \mathrm{C}$ (by $25 \%$ ) causes the increase of the mass transfer coefficient from 2.75 to $4.2 \cdot 10^{-2} \mathrm{~kg} / \mathrm{s} / \mathrm{m}^{2}$ (by $50 \%$ ).

The dependence of the mass transfer coefficient on the air velocity and input water temperature is calculated under the hydraulic displacement layer thickness $\delta$

$$
\beta c=\frac{\rho D}{\delta}
$$

and compared with the experimental results (see Eq. (16)), as shown in Fig. 11.
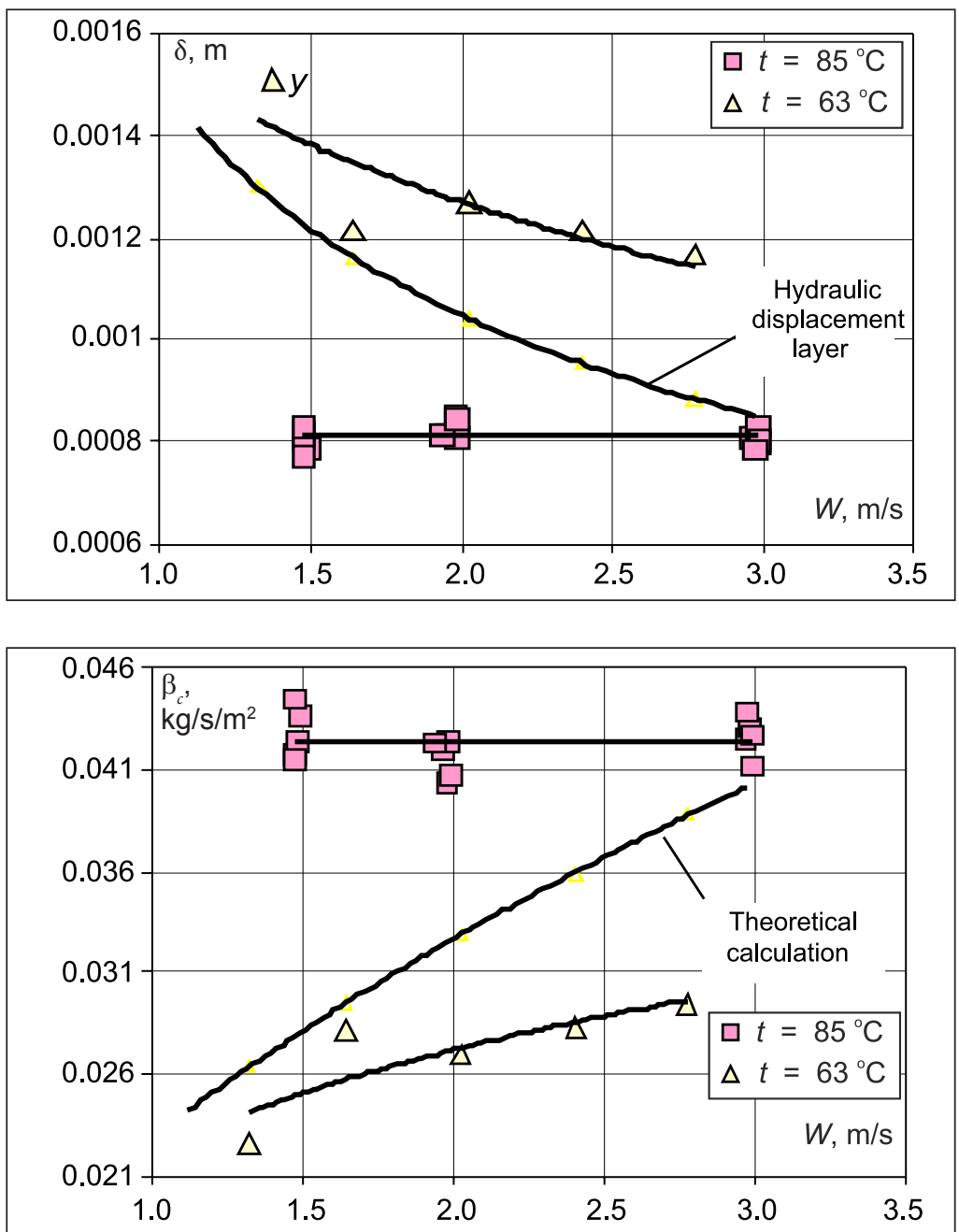

Fig. 10. Dependence of the thickness of the hydraulic displacement layer and diffusion layer on the air velocity and input water temperature

Fig. 11. Dependence of the mass transfer coefficient on the air velocity and the input water temperature 
As it is shown, in the range of high air velocities which are more than $2 \mathrm{~m} / \mathrm{s}$ the deviation of the experimental values of the mass transfer coefficient from the theoretical ones is up to $30 \%$. This is explained by increasing the temperature of water from $63{ }^{\circ} \mathrm{C}$ to $85^{\circ} \mathrm{C}$ that intensifies heat transfer and that the thickness of the hydraulic displacement layer obtained theoretically does not take into consideration water film temperature.

\section{CONCLUSIONS}

The mass transfer coefficient and factors influencing it are evaluated at the input air temperature $20{ }^{\circ} \mathrm{C}$ and the water film temperatures $63{ }^{\circ} \mathrm{C}$ and $85{ }^{\circ} \mathrm{C}$. It was determined experimentally that the growth of the temperature of the input water film directly increases the mass transfer efficiency and the change of the air velocity practically does not influence it. The diffusion mass transfer component is found in one order higher than the convection mass transfer component at the input water film temperature 63 and $85^{\circ} \mathrm{C}$.

The thickness of the diffusion layer was compared with the theoretically obtained hydrodynamic displacement layer. The mass transfer coefficient is found experimentally and calculated theoretically based on the thickness of the hydraulic displacement layer. It is demonstrated that the difference between experimental results and theoretical calculation does not exceed $30 \%$ in the range of the air velocities $(2.0-3.0) \mathrm{m} / \mathrm{s}$.

\section{Abbreviations}

$h, \mathrm{~J} / \mathrm{kg}$ - enthalpy,

$v, \mathrm{~m} / \mathrm{s}$ - velocity,

$\rho, \mathrm{kg} / \mathrm{m}^{3}$ - density,

$D, \mathrm{~m}^{2} / \mathrm{s}$ - mass diffusion coefficient,

$t, \mathrm{C}$ - temperature,

$\alpha, \beta c$ - heat and mass transfer coefficients,

$G, \mathrm{~kg} / \mathrm{s}$ - flow rate,

$c, \mathrm{~J} / \mathrm{kg} / \mathrm{K}$ - heat capacity,

$v, \mathrm{~m}^{2} / \mathrm{s}$ - viscosity,

$m, \mathrm{~kg}$ - mass,

$\varphi$ - relative humidity,

$d, \mathrm{~kg} / \mathrm{kg}$ - absolute humidity,

$W, U, \mathrm{~m} / \mathrm{s}$ - air and water film velocity,

$B, \mathrm{~Pa}$ - atmospheric pressure,

$\omega$ - mass fraction of vapour,

$\dot{m}, \mathrm{~kg} / \mathrm{m}^{2} / \mathrm{s}$ - specific flow rate,

$f, \mathrm{~m}^{2}$ - contact area,

$Q$, Wt - heat power,

$R$ - Pearson correlation coefficient,

$D m, \mathrm{~kg} / \mathrm{m}^{2} / \mathrm{s}$ - mass diffusion flow,

$D k, \mathrm{~kg} / \mathrm{m}^{2} / \mathrm{s}$ - mass convection flow,

$\delta, \mathrm{m}$ - hydraulic displacement layer thickness,
$\Delta y$ - diffusion layer thickness,

$V, \mathrm{~m}^{3}$ - volume,

$x, y, m$ - longitudinal and transverse coordinates.

\section{Indexes}

$1,2,3$ - vapour, air and water film respectively,

$s, w$ - humid air in stream and near the water film,

ls - loss,

in, out - input and output, respectively.

Received 6 June 2013

Accepted 28 March 2014

\section{References}

1. Stabat P., Marchio D. Simplified model for indirectcontact evaporative cooling-tower behavior. Applied Energy. 2004. No. 78. P. 433-451.

2. Qureshi B. A., Zubair S. M. A complete model of wet cooling towers with fouling in fills. Applied Thermal Engineering. 2006. No. 26. P. 1982-1989.

3. Naphon P. Study on the heat transfer characteristics of an evaporative cooling tower. International Communications in Heat and Mass Transfer. 2005. Vol. 32. P. 1066-1074.

4. El'-Talla A. A. Teploobmin pry kontaktniy kondensatsiyi $v$ trubakh: Ph. D. Thesis in Engineering Science. Kyiv Polytechnical Institute, 1997. 220 p.

5. Hladkov V. A., Aref'ev Yu. N., Ponomarenko V. S. Ventylyatornie hradyrny. Moskva: Stroyyzdat, 1976. $216 \mathrm{p}$.

6. Heshev P. Y., Kovalev O. P., Tsvelodub O. Yu., Yakubovskyy Yu. V. Teplomassoobmen pry kontakte horyacheho haza so stekayushchey plenkoy zhydkosty. YFZh. 1984. T. 46. No. 3. P. 428-432.

7. Tuz V. E. Kontaktniy teplomassoobmenniy apparat $s$ porystoy nasadkoy dlya toplyvnoy systemi promishlennoy gas turbine: Ph. D. Thesis in Engineering Science. Kyiv Polytechnical Institute, 1989. 200 p.

8. Berman L. D. Ysparytel'noe okhlazhdenye tsyrkulyatsyonnoy vody. Moskva-Leningrad: HEY, 1957. 424 p.

9. Alekseev V. P. Yssledovanye protsessov teplo- y massoobmena $v$ apparatakh kholodylnikh ustanovok s rehulyarnimy nasadkamy: Ph. D. Thesis in Engineering Science. Odesa, 1969. 246 p.

10. Heorhalina O. R. Modelyuvannya ta optymizatsiya plivkovykh okholodzhuvachiv: $\mathrm{Ph}$. D. Thesis in Engineering Science. Odesa: Kyiv Polytechnical Institute, 2004. 185 p.

11. Petruchyk A. Y., Fysenko S. P. Matematycheskoe modelyrovanye ysparytel'noho okhlazhdenyya plenok vodi $v$ hradyrnyakh. YFZh. 1999. T. 72. No. 1. P. 43-49. 
12. Antonyk V. V., Petruchyk A. Y., Solodukhyn A. D., Stolovych N. N., Fysenko S. P. Teplomassoobmen pry ysparytel'nom okhlazhdenyy plenok vodi na dvukh vertykal'nikh plastynakh. Trudi IV Mynskoho mezhdunarodnoho foruma po teplomassoobmenu. 2000. P. 314325.

13. Chou Y., Ruey-Jen Y. The evaporation of a saturated porous layer inside an inclined airflow channel. International Journal of Heat and Fluid Flow. 2007. No. 28. P. 407-417.

14. Saouli S., Boumaza M., Settou N., Aiboud-Saoili S., Daguenet M. Numerical study of the evaporation of a falling Ostwaldian film along an inclined flat plate into a laminar stream of humid air. 4th International Conference on Heat Transfer, Fluid Mechanics and Thermodynamics (HEFAT 2005), September 19-22, 2005, Cairo, Egypt.

15. Feddaoui M., Meftah H., Mir A. The numerical computation of the evaporative cooling of falling water film in turbulent mixed convection inside a vertical tube. International Communications in Heat and Mass Transfer. 2006. No. 33. P. 917-927.

16. Zhang H., Tao W., He Y., Zhang W. Numerical study of liquid film cooling in a rocket combustion chamber. International Journal of Heat and Mass Transfer. 2006. No. 49. P. 349-358.

17. Ekkert E. R., Dreyk R. M. Teoryya teplo- y massoobmena. Moskva-Leningrad: Hosudarstvennoe enerhetycheskoe yzdatel'stvo, 1961. $681 \mathrm{p}$.

18. Kuzmenko I. M. Hidrodynamika ta teplomasoobmin v protytokovomu kontaktnomu vyparovuvachi $z$ sitchastoyu hofrovanoyu nasadkoyu: Ph. D. Thesis in Engineering Science. Kyiv Polytechnical Institute, 2003. $200 \mathrm{p}$.

19. Schlichting H. Boundary Layers Theory. Springer, 1979. 815 p.
Igor Kuzmenko, Roman Prokopets

\section{MASĖS MAINŲ AUŠINIMO BOKŠTE TEORINIAI IR EKSPERIMENTINIAI TYRIMAI}

\section{Santrauka}

Straipsnyje pateikiami eksperimentiškai ir teoriškai aušinimo bokštuose nustatyti masès mainų rezultatai. Apskaičiuota difuzijos ir konvekcijos komponenčių įtaka masès mainams. Palyginimas atskleidè, kad konvekcijos komponentès įtaka masès mainams aušinimo bokšte yra nereikšminga.

Difuzijos sluoksnio storis apskaičiuotas ir palygintas su teoriškai gautu išstūmimo sluoksnio storiu. Masès mainų koeficientas nustatytas vadovaujantis išstūmimo sluoksnio storiu. Parodyta, kad skirtumas tarp skaičiavimo rezultatų ir eksperimentinių duomenų sudaro ne daugiau $33 \%$ oro greičio $(1,3-3,0) \mathrm{m} / \mathrm{s}$ intervale.

Raktažodžiai: aušinimo bokštas, masès mainai, išstūmimo sluoksnis, Merkel lygtis

Игорь Кузьменко, Роман Прокопец

\section{ТЕОРЕТИЧЕСКИЕ И ЭКСПЕРИМЕНТАЛЬНЫЕ ИССЛЕДОВАНИЯ МАССООБМЕНА В ГРАДИРНЕ}

\section{Резюме}

В данной статье представлены экспериментальные и теоретические результаты коэффициента массообмена в градирне. Рассчитан вклад диффузионного и конвективного массообмена, установлено, что вклад конвективного массообмена в градирне незначителен.

На основе данных эксперимента определена толщина диффузионного слоя и сопоставлена теоретически рассчитанной толщиной слоя вытеснения. Коэффициент массообмена рассчитан по величине слоя вытеснения и показано, что разница между экспериментальными и расчетными величинами не превышает 33 \% в диапазоне скорости воздуха (1,3-3,0) м/с.

Ключевые слова: градирня, массообмен, слой вытеснения, уравнение Меркеля 